\title{
REKLAMA W SZTUCE, SZTUKA W REKLAMIE A PRZESTRZEŃ PUBLICZNA
}

\author{
Agnieszka Chęć-Małyszek \\ Katedra Architektury, Urbanistyki i Planowania Przestrzennego, Wydział \\ Budownictwa i Architektury, Politechnika Lubelska \\ Department of Architecture, Urban and Spatial Planning, Faculty of Civil \\ Engineering and Architecture, University of Lublin \\ e-mail: a.chec-malyszek@pollub.pl
}

\begin{abstract}
Streszczenie. Dawniej reklama była prymitywnym porozumieniem producenta i konsumenta. Od początku XX wieku reklama rozpowszechniła się na skalę masową. Powszechność wpływu reklamy na życie człowieka nabrała socjokulturowego wymiaru. Mówi się już nie tylko o tym, że reklama zmienia życie człowieka ale również, że kształtuje jego osobowość. Celem reklamy jest zazwyczaj przekazywanie informacji o produkcie, przekonywanie odbiorców o jego zaletach, wywoływanie zainteresowania i pobudzanie pragnienia posiadania towaru. Stosując jednak reklamę, należy pamiętać o fakcie dwoistej jej natury: z jednej strony ma ona charakter sztuki kreatywnej, z drugiej strony chodzi o jej skuteczność i efektywność oddziaływania. Poniższy artykuł jest próbą ukazania cienkiej granicy pomiędzy tym co uznawana jest za działo sztuki a tym co jest komercją. Jest przedstawieniem zmian jakie zaszły w sztuce, które przyczyniły się do zatarcia granic pomiędzy tym co twórcze i odtwórczy, tym co publicznea tym co nią nie jest.
\end{abstract}

Słowa kluczowe: reklama, sztuka, przestrzeń publiczna, architektura, dzieło sztuki, kicz

\section{WPROWADZENIE}

Sztuka w reklamie czy reklama w sztuce? Jaki charakter ma sztuka w dzisiejszych czasach? Co możemy nazwać sztuką a co już reklamą? Gdzie jest granica pomiędzy nimi? Powszechne staje się zjawisko obcowania ludzi ze sztuką, właśnie przez reklamę, która stała się nieodzownym elementem naszego życia. Możemy ją spotkać na każdym kroku w sklepie, telewizji, na plakacie czy w skrzynce na listy; niemal ,atakuje” nas ze wszystkich stron. Z kolei sztuka od lat była, jest i będzie wykorzystywana w reklamie choć pozostaje pytanie w jak dużym stopniu oraz jaki ma to cel?

\section{POJECIE SZTUKI I REKLAMY}

Sztuka wywodzi się już od czasów starożytnych gdzie oznaczała wszelką twórczość wykonywaną według pewnych reguł pojmowanych w sposób techniczny, a nie artystyczny. Czas odrodzenia to wyzwolenie dla sztuki i nowe jej zrozumienie a koniec XVII wieku to już pełna świadomość tego, że w sztuce ważna jest nie tylko wiedza ale i umiejętności. To co w wieku XVII nazwano sztukami pięknymi w XVIII wieku nazwano po prostu sztuką. Pojęcie sztuk pięknych odnosiło się wyłącznie do sztuk plastycznych, muzyki czy teatru a w późniejszym okresie dołączyły do nich malarstwo, rzeźba i architektura. Wiek XX dla sztuki to podważenie poglądu o jej nienaruszalności oraz pojawienie się niepewności, która pozostaje po dzień dzisiejszy.

Pojęcie reklamy od lat podlega ciągłym zmianom. Początkowo stosowna była w postaci kamiennych napisów i szyldów na ścianach budynków, pełniących funkcję komunikacyjno-informacyjną. W starożytnej Grecji pojawiły się pierwsze reklamy pisane, które informowały o wydarzeniach kulturalnych i sportowych. Dopiero wynalezienie druku przez Gutenberga zrewolucjonizowało reklamę. W tym czasie powstały pierwsze reklamy graficzne w prasie. Początkowo niewiele miała wspólnego z obecną reklamą, były to raczej ogłoszenia zawierające 
nazwę i informacje o produkcie, rzadko towarzyszył im rysunek czy hasło. Koniec wieku XIX i początek XX to zmiana wyglądu reklam, wraz ze zwiększaniem się możliwości technicznych, reklamy stały się bardziej skomplikowane i ciekawsze. Lata dwudzieste to już masowe powstawanie agencji reklamowych, aż do chwili obecnej. Tworzone przez nie reklamy stała się nieodzownym elementem ludzkiego życia. O ile w latach pięćdziesiątych pojmowano reklamę jako wyłączny czynnik towarzyszący aktowi kupna i sprzedaży, o tyle w latach sześćdziesiątych jawi się ona jako kompleksowe zjawisko kulturotwórcze rozpowszechniające produkt jaki i sposób życia. Według najczęściej przytaczanych definicji reklamy American Marketing Association: ${ }^{1}$ Reklam jest każda platna forma nieosobistej prezentacji i popierania idei dóbr oraz ustug przez ściśle określonq, zainteresowana osobę a w innej definicji jawi się jako zespót środków w celu zainteresowania i zachęcenia do zakupu określonych towarów $i$ ustug. Obecnie reklama pełni funkcję prezentacji, wpływa na popyt, utrzymuje rynek zbytu i pojawia się praktycznie wszędzie. ${ }^{2} \mathrm{Z}$ powyższych definicji wynika iż reklama jest wielofunkcyjna, gdyż pełni zarówno ekonomiczną, kulturową i estetyczną funkcję, co umożliwia rozpatrywanie jej jako sztuki. $Z$ jednej strony reklamę możemy zaliczyć do sztuki użytkowej i choć wykorzystuje ona sztukę do swoich celów nie należy do żadnej dziedziny sztuki. Zatem możemy śmiało stwierdzić, że reklama pełni kilka funkcji co daje możliwość rozpatrywania jej zarówno w aspekcie kulturowym jak i estetycznym.

\section{REKLAMA W SZTUCE, SZTUKA W REKLAMIE}

Reklama, na przestrzeni dziesięcioleci, przestała być po prostu funkcjonalnym przekazem mającym informować o danym produkcie, a stała się artystyczną formą wyrazu. Pewne jej złożenia, jak przedstawienie w sposób zachęcający produktu i nakłonienie do jego zakupu, nie uległy zmianie. Coraz większa konkurencja na rynku reklamy spowodowała, że zaczęto szukać nowych, innowacyjnych rozwiązań dla reklamy czego wytworem stały się małe dzieła sztuki. Zabiegi te doprowadziły do tego, iż reklama uznana została za taką samą formę sztuki jak rzeźba czy malarstwo. Ale póki co, nawet najbardziej artystyczne reklamy nie są traktowane jako dzieła sztuki głównie z powodu ich komercyjnego wymiaru.

Sztuka utraciła swe tradycyjne znaczenie, światopogląd wraz z wszystkimi kierunkami artystycznymi w momencie narodzin awangardy. Zaczęła wkraczać w codzienność wykorzystując powszechnie przedmioty codziennego użytku, podobnie jak to robi reklama. Jednym z pierwszych artystów, który zrewolucjonizował pojęcie sztuki był Marcela Duchamp i wystawiony przez niego w 1917 roku w Nowym Jorku pisuar zatytułowany „Fontanna”. Dzieło okrzyknięte zostało mianem skandalu i wywarło na zwiedzających spore wrażenie. Marcel Duchamp dokonywał w ten sposób rewolucyjnej zmiany w pojmowaniu sztuki, także w relacjach pomiędzy sztuką i rzeczywistością. Duchamp uważał, że rzecz spetniająca funkcję użytkową nie może stać się dziełem sztuki, ponieważ stuży do czegoś innego niż jej podziwianie jednak jeżeli tę sama rzecz umieścimy w muzeum, wyeksponujemy, oddzielimy od odbiorców muzealnym sznurem i nadamy jej tytut, nieoczekiwanie przeistoczy się ona w przedmiot estetyczny.3 Zatem najważniejsze znaczenie ma nie sam przedmiot lecz otoczenie w jakim występuje czy się znajduje. Poprzez taką artysta pokazuje, że granica między sztuką a nie-sztuką jest bardzo płynna i umowna.

1 Kuśmierski S., Reklama jest sztuka, Warszawa 2000, s. 57.

2 Nowa Encyklopedia Powszechna PWN, Warszawa, s. 487.

3 Tomkins C., Duchamp. Biografia, Poznań 2001, s. 97. 

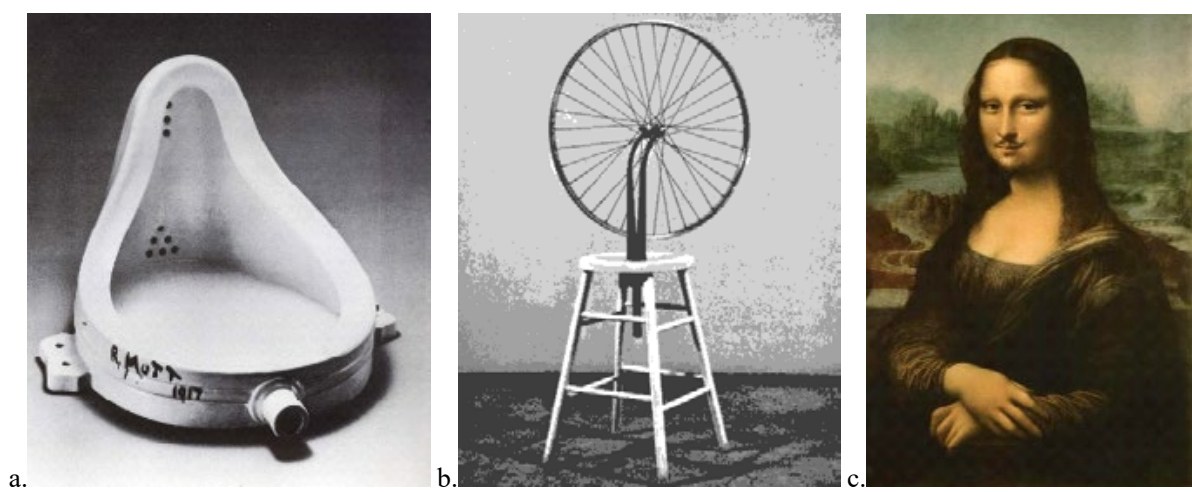

Ryc. 1 a. Rzeźba „Fontanna 1917 Marcel Durchamp - Muzeum Sztuki w Filadelfii.; b. Koło rowerowe 1913 Marcel Duchamp - Museum of Modern Art. Nowy York; c. Mona Lisa 1965 Marcel Duchamp - Norton Simon Museum Fig. 1 a. Fountain 1917 by Marcel Duchamp-Philadelphia Museum of Art: Fountain; b. Bicycle Wheels by Marcel Duchamp- Philadelphia Museum of Art.; c. Mona Lisa 1965 by Marcel Duchamp- Norton Simon Museum

Duchamp po przez swoją twórczość wymierzył policzek w sztukę klasyczną, zawłaszczając i wykorzystując obraz „Mona Lisa” Leonarda da Vinci w świecie reklamy masowej. Jest to świetny przykład pasożytnictwa, którego dopuściły się znane marki firm, oparty na efekcie niezgodności i zestawianiu niepasujących do siebie elementów. Efektem tych reklam, które przez prostą technikę fotomontażu parodiują znany obraz jest tylko i wyłącznie kicz. Dziś co prawda zyskujący coraz większe znaczenie. Jak pisze Stanisław Kuśmierski w książce „Reklama jest sztuką”: „kicz ma swoją wielomilionową publiczność i dlatego reklama nie mogła przejść obok niego obojętnie. Jeśli go świadomie wykorzystuje do swoich celów i dba o określony poziom, to nie jest to wcale najgorsze" 4

W erze pop-kultury sztuka i reklama wzajemnie się przenikają. Symbolem tego procesu są prace Andy'ego Warhola, w których wykorzystał wizerunek produktów konsumpcyjnych obecnych w przeciętnym, amerykańskim domu. Prace te charakteryzuje, silny kontrast kolorystyczny oraz techniką serigrafii. Artysta traktował wszystko co malował przedmiotowo i bez zbędnych emocji. Puszka Coca-Coli, zupa pomidorowa Campbell, Proszek Brillo czy banknoty dolarów miały dla niego taką samą wartość jak podobizny ludzi mu współczesnych. Najbardziej znane prace Andy'ego to puszka zupy Campbell's i Coca-Coli oraz pudełko proszku Brillo. Przedmioty przedstawione jak o małe dzieła sztuki, które rozpoczynają erę reklamy. Andy Warhol jako pierwszy artysta zgodził się na współpracę z marką Absolut i stworzył dla nich projekt będący jednym z najlepszych przykładów wykorzystania w reklamie motywów artystycznych. Dzięki jego twórczości marka zbudowała indywidualny styl kampanii reklamowych, tworząc z butelki Absolut ikonę popkultury. 
a.

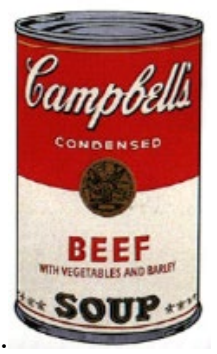

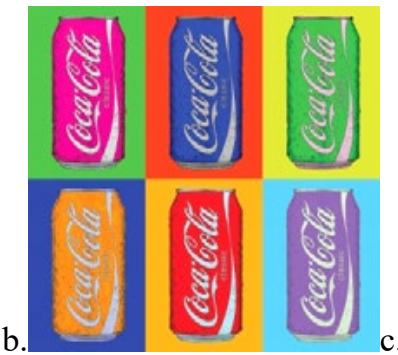
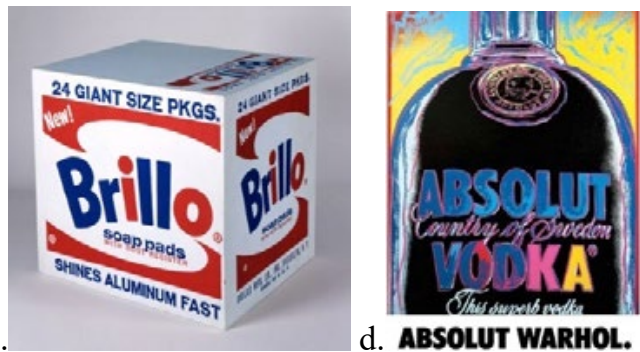

Ryc. 2 a. Puszka zupy Campbell's,; b.Puszka Coca-Coli; c. Pudełko proszku Billo; d. Projekt dla marki Absolut - Andy Warhol

Fig. 2 a. Campbell's soup cans; b. Coca-Cola cans; c. Brillo Box powder; d. Project for the brand Absolut - Andy Warhol projects

Andy Warhol tworzył sztukę, która po przez dobór „zwykłych” produktów, stawała się reklamą posiadającą cechy dzieła sztuk. Wśród innych artystów, znajdziemy wiele przykładów gdzie dzieło sztuki zostaje wykorzystane w reklamie danego produktu. Zabieg ten ma na celu zwrócić na dany produkt uwagę, jednocześnie podkreślając jego wyjątkowość. Poza reklamami inspirowanymi pop-artem możemy znaleźć kampanie, których podstawą stały wielkie dzieła znanych artystów sprzed wielu lat. Art of Renaissance - Christiana Louboutina, słynne dzieło Van Gogha - reklama sieci sklepów Ikea czy Volkswagen.
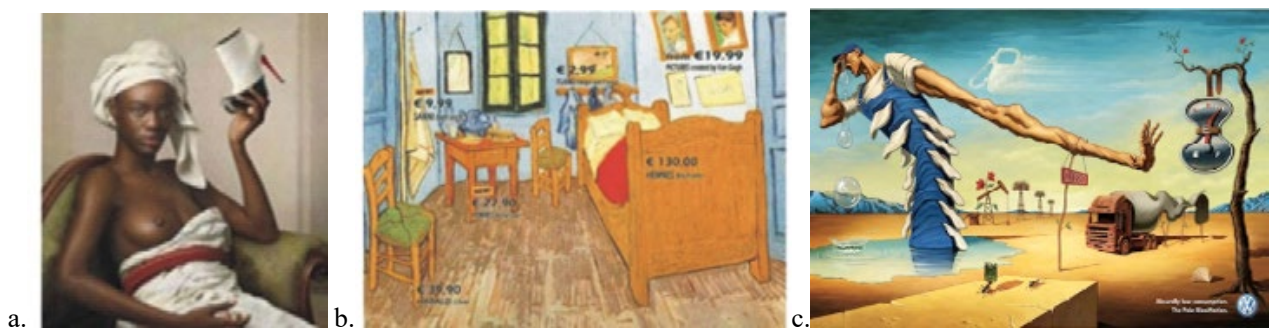

Ryc. 3 a. kampania Christiana Louboutina - Art of Renaissance; b. Van Gogh reklama sieci sklepów Ikea; c. Surrealiztyczny bilbord dla Volksvagena

Fig. 3 a. Campaign Christian Louboutin - Art of the Renaissance; b. Van Gogh Ikea advertising network; c. Surrealistic advartisment for Volkswagen

Znani artyści, którzy w swojej twórczości wykorzystują znane dzieła sztuki to David LaChapelle i Oliviero Toscani, uznawani za wizjonerów billboardów reklamowych. Dla przykładu David LaChapelle „,beatyfikował” Michaela Jacksona, a czarnoskóremu raperowi Kanye Westowi założył koronę cierniową „Pasja Chrystusa”. W swoich pracach często opiera się na motywach religijnych.

Z kolei Oliviero Toscani, włoski fotograf reklamowy, uważany jest za przedstawiciela nurtu reklamy szokującej. Jego twórczość spowodowała, że reklama stała się sztuką pozbawioną jakichkolwiek zasad. Toscani od samego początku twórczości nie poddawał się klasycznym stereotypom rządzącym reklamą. Jako przykład możemy podać jego pracę dla producenta jeansów „Jezus” a sławę przynosi mu współpraca z producentem odzieży Benetton. 


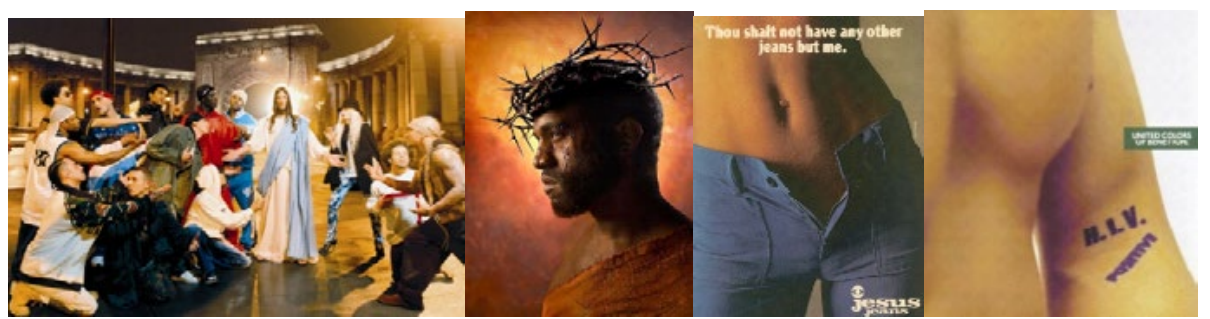

Ryc. 4. Przykłady plakatów reklamowych, które w niekonwencjinalny sposób promują znane produkty lub maki

Fig. 4. Examples of advertisements which promote in an unconventional way product known or poppies

Styl zapoczątkowany przez Andy’ego Warhola, choć obecny w sztuce i kulturze od tak dawna, po dzień dzisiejszy wykorzystywany jest w reklamie. Popularne jest zwłaszcza korzystanie z kolorowych, kontrastowych portretów sławnych ludzi. Reklama, która wykorzystuje wizerunek znanej i poważanej osobistości w sposób niekonwencjonalny dziś już nikogo nie dziwi i nie szokuje, ale w czasach Warhola było czymś innowacyjnym. Takie przykłady wykorzystywania w dzisiejszej sztuce i reklamie stylu pop-art można mnożyć, ale styl ten wykorzystywany jest jednak nie tylko w reklamie, sztuce, ale również w projektowaniu ubrań, rzeczy codziennego użytku czy wystroju wnętrz. Wydaje się, że na dobre zagościł w naszej kulturze, co wcale nie dziwi, ponieważ jego przekaz jest dość prosty i zrozumiały dla przeciętnego odbiorcy. Zatem można stwierdzić, że reklama wykorzystuje sztukę do swych celów i mimo jej aspiracji do żadnej z dziedzin sztuki nie należy. Pasożytuje na dziełach wielkich artystów, budując dystans konsumentów. Zabiegi te mają na celu odwoływanie się do znanego autorytetu i uznanych wartości, wzbudzając w odbiorcy pozytywne emocje i skojarzenia. Sztuka staje się więc źródłem wielu wartościowych inspiracji do tworzenia oryginalnych reklam.

W historii możemy znaleźć wiele przykładów, które pokazują, że reklama jedynie wykorzystuje sztukę do swych celów. Jako przykład możemy podać firmę Red Bull - obraz Michała Anioła czy Samsung - dzieło Van Gogha. Twórcy tych reklam chcąc przyciągnąć uwagę widza posłużyli się efektem niezgodności, po przez zestawienie ze sobą niepasujących elementów.
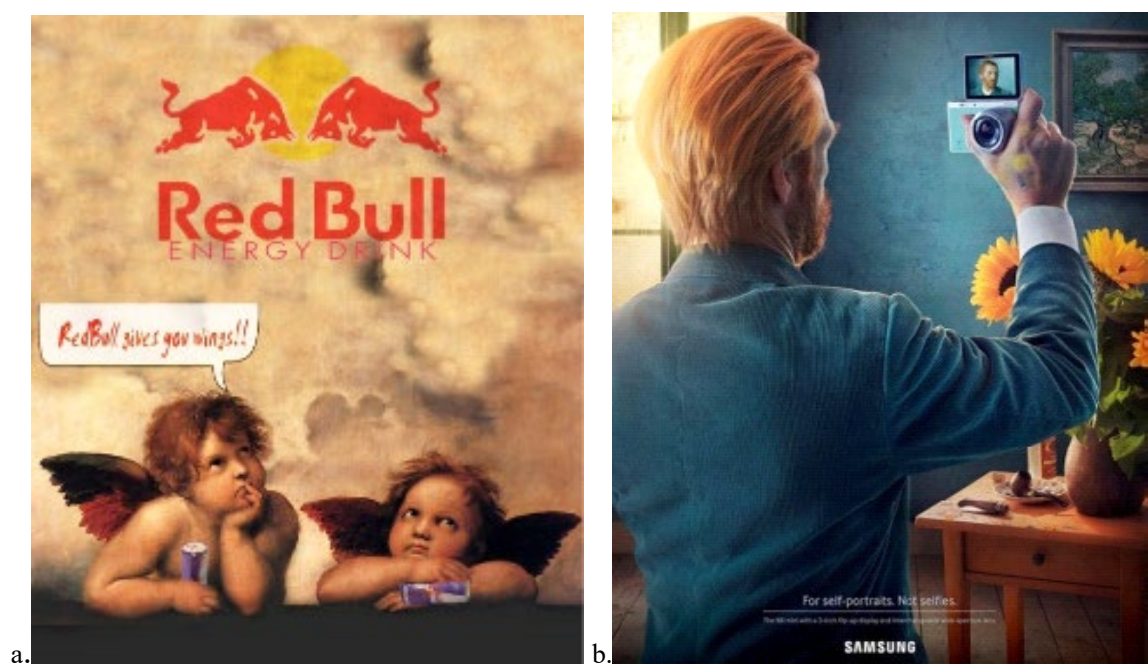

Ryc. 5. a. Plakat reklamowy Red Bull wykorzystujący obraz Michała Anioła;

b. Plakat reklamowy fimy Samsung wykorzystujący dzieło Van Gogha

Fig. 5 a. Advertising poster Red Bull using the image of Michel Angelo;

b. Advertising poster fimy Samsung uses the work of Van Gogh 
Natłok reklamy powoduje iż mamy wrażenie, że sama przychodzi do odbiorcy, z kolei sztuka stała się domeną wąskiej grupy koneserów. Nikogo nie dziwi wystawienie kontrowersyjnego dzieła w galerii, które w silny sposób oddziaływane na odbiorcę. Z uwagi na miejsce oraz fakt iż jest to dzieło artysty - nie szokuje. Z kolei to samo dzieło pokazane publicznie na ulicy wywołuje oburzenie czy nawet bulwersuje prowadząc do głośnej dyskusji na ten temat. To właśnie charakteryzuje reklamę, że jeśli o niej mówią to znaczy że trafiła do odbiorcy. Z kolei w przestani publicznej znika dystans pomiędzy prezentowanym obrazem a odbiorcą, który mamy w stosunku do dzieła sztuki znajdującego się w galerii. Artysta nie musi thumaczyć się ze swojej twórczości jeśli dzieje się to w galerii. I tak obraz, na którym przedstawi kilka kolorowych plam czy kwadratów jest nazwany sztuką i to nie dlatego, że namalował go sławny malarz, ale dlatego, że został umieszczony w galerii. Kwalifikacja dzieła poza galerią jako przedmiotu sztuki nie jest już taka łatwa.

Reklama ze względu na posiadane cechy sztuki użytkowej ma z nią ścisły związek. Jednak czy można nazwać ją sztuką? W książce „Rynek sztuki” M.Golka uwidacznia zasadnicze różnice pomiędzy reklamą a sztuką. Według niego ...sztuka ma przestanie artystyczne, intelektualne czy społeczne. Po drugie, motywy tworzenia sztuki bywaja (choć nie zawsze) bezinteresowne. Po trzecie, reklama musi być zawsze czytelna i zrozumiała, musi być oparta na kodzie powszechnie dostępnym, musi być zawsze przektadana na język werbalny - a więc musi nadawać się do opowiedzenie, o co w danym wypadku chodzi. Aby tak się stało, musi wykorzystywać najbardziej uzasadnione $w$ kulturze, uniwersalne konwencje znaczeniowe. Poza tym wolno wszystko: wykorzystywać metafory, skróty, symbole, itp., tyle że musza być one zrozumiałe. Tymczasem sztuka nie musi, a nawet nie powinna zdaniem wielu twórców $i$ estetów nie powinna byś w petni i jednoznacznie czytelna. Musi ona zawierać pewien element niejasności. Poza tym cecha sztuki jest niepowtarzalność jej wytworów, gdy tymczasem właściwościa reklamy jest programowe stosowanie powtórzeń nieraz tysiacach znaków, symboli, plansz, itp.: Ta powtarzalność jest jej istota. Dzięki niej wpływa się na zachowanie odbiorcy reklamy, czynią z niego klienta towarów. Następna cecha sztuki jest większa czystość mediów: albo stowo albo obraz, albo dźwięk. Nawet w filmie czy w teatrze te nośniki znaczeń, choć zespolone, zachowuja wtasna tożsamość. Tymczasem w reklamie mamy zawsze kod mieszany: wzrokowo-werbalny i audialny. 5

Kryteria te wydają się być trafne, jednocześnie przedstawiają cechy jakie reklama musi posiadać aby można ją było nazwać sztuką. Reklama zbliża się do sztuki w momencie gdy zaczynają w niej dominować funkcje estetyczne, wizualne czy komunikacyjne. $Z$ kolei aby można ją było nazwać sztuką musi posługiwać się środkami twórczymi jak obraz, słowo czy wartość estetyczna. W końcu twórcami reklam są plastycy, graficy, fotograficy i muzycy, którzy na co dzień obcują ze sztuką. Reklamę można nazwać sztuką wtedy gdy końcowy efekt pracy nad nią jest trudno przewidzieć. Zatem reklama może być tak samo nieprzewidywalna jak sztuka - a to właśnie jest jej istota.

Marshall McLuhan, słynny kanadyjski teoretyk komunikacji, powiedział kiedyś, że Reklama jest najwspanialsza forma sztuki XX wieku. W powyższym stwierdzeniu możemy doszukać się prawdy, ze względu na to, iż sztuka nie posiada swojej ścisłej definicji co powoduje, że reklama może przybierać formę sztuki. Reklama jest wytworem przemyślanym i udoskonalonym przez artystę.

W dzisiejszych czasach trudno jest zauważyć cienką granicę pomiędzy artystą a nie artystą, pomiędzy sztuką a nie sztuką. Można mówić, że reklama to po części sztuka, która zawsze wzbudzała kontrowersje niezależnie od tego, czy mówi się o niej dobrze, czy źle. Najważniejsze dla reklamy, jest to że się o niej mówi, bo to jest jej istotą, czyniąc ją wyjątkową i niepowtarzalną. Celem jej jest pozyskanie jak największego grona odbiorców, które będzie 
o niej mówić. Może również występować jako sztuka sprzedaży lub być na tyle wykreowana, że sama stanie się sztuką. A więc nie każda reklama jest sztuką, chociaż posługuje się środkami artystycznymi, wymaga wyczucia estetyki i przygotowania artystycznego. Reklama, która może być uważana za sztukę, powinna zawierać w sobie nie tylko wartości ekonomiczne, ale też takie, które kształtują świat jednostki, wpływając na jej codzienne zachowanie - właśnie wtedy można traktować jako sztukę. Niektórzy uważają, że wykorzystanie w reklamie dzieła sztuki stworzonego przez wielkiego artystę jest profanacją, jednak twórcy reklam mają w tym swój określony cel. Przede wszystkim przez ten zabieg odwołują się do znanego autorytetu czy wartości, wzbudzając w odbiorcy pozytywne skojarzenia. Sztuka może być pod tym względem źródłem wielu wartościowych inspiracji do tworzenia oryginalnych reklam po przez swoje walory estetyczne i koncepcyjne. Coraz częściej mówi się też, że to nie artysta tworzy sztukę, ale sztuka tworzy artystę a media promują jego twórczość.

Sztuka od zawsze była nieograniczonym źródłem inspiracji, nieustannie przejawiającym się w wielu dziedzinach naszego życia. Jest doskonałym komentarzem do otaczającego nas świata. Projektanci mody, malarze, graficy, fotografowie, a także spece od reklamy i marketingowcy w swojej pracy niezmiennie korzystają z dorobku kulturalnego ludzkości. Ci ostatni nie raz zachwycili nas oryginalnym i interesującym przełożeniem danego dzieła na swoje potrzeby. Dzięki temu zyskiwało nowe znaczenie.

A więc możemy przyjąć, że to media tworzą sztukę, bo pośrednio wpływają na kształt twórczości artystów od nich zależnych. Granica pomiędzy sztuką a nie sztuką jest bardzo cienka, dodatkowo sami artyści coraz chętniej angażują się w tworzenie reklam ze względu na dużą publikę. Sztuka dociera do mas właśnie dzięki reklamie, która po przez swój ogromny zasięg sama przychodzi do odbiorcy. Jednak obcowanie ze sztuką osobiście ma o wiele silniejszy przekaz niż odbiór tej samej sztuki przez Internet czy telewizję.

Reklama z kolei to nieustanny dialog obrazu z przypadkowymi widzami. Jednocześnie komunikuje się ona z odbiorcą pełniąc rolę informacyjną, zachęcającą i doradczą. Prawda jest taka, że niektórzy ludzie nigdy by nie dowiedzieli się o istnieniu pewnych dzieł malarskich, muzycznych czy poetyckich gdyby nie reklama. Na tej podstawie możemy śmiało stwierdzić, że powszechność reklamy i wykorzystanie przez nią dzieł wielkich artystów przyczyniło się do rozpowszechnienia sztuki.

Zatem reklama i sztuka przenika się wzajemnie będąc dla siebie źródłem inspiracji jednocześnie uzupełniając się wzajemnie. Sztuka jest jedną z płaszczyzn, w której tworzy się gust, smak, kreuje styl i powstają trendy. Reklama spełnia dokładnie te same funkcje.

\section{REKLAMA W PRZESTRZENI PUBLICZNEJ}

Również architektura i sztuka od zawsze żyły w symbiozie, inspirując się nawzajem. Dyscypliny te pozostają w dialogu i delikatnie się ze sobą stykają. Definicją i funkcją architektury jest ciągła zmiana, która przychodzi wraz z rozwojem sztuki nowoczesnej.

Reklama w przestrzeni publicznej stanowi nieodłączną część życia społecznego, jednocześnie pełni bardzo istotną rolę - informacyjną. Możemy powiedzieć że stan przestrzeni publicznej świadczy o kulturze kraju i poziomie rozwoju estetycznego zamieszkującego go społeczeństwa. W mediach takich jak radio czy telewizja, istnieją regulacje określające liczbę i sposób nadawania reklam, ale brak ich w przestrzeni publicznej. Obcując na co dzień z wizualnym chaosem, zaczynamy traktować go jako stan normalny i przestajemy go dostrzegać. Nie wnosząc sprzeciwu, godzimy się na nieporządek i bylejakość w otaczającej nasz przestrzeni, tracąc przy tym poczucie harmonii. W dużych miastach tablice reklamowe pokrywają większość ścian budynków tworząc bałagan, którzy przysłania krajobraz miasta. Dodatkowo całe budynki pokryte są gigantycznymi reklamami, który nie dość że przysłaniają architekturę budynku dodatkowo psują ogólny wizerunek miasta. Drogi wylotowe z miast oblepione są tysiącami tablic reklamowych. Słupy trakcyjne, latarnie, pokryte są ogromem plakatów 
i ulotek. Mało tego, reklamy coraz śmielej pojawiają się tam, gdzie szukamy ciszy i spokoju, w miejscach wypoczynku: na plażach, stokach narciarskich, terenach zielonych czy trasach turystycznych. Wskakują nam przed oczy, gdy jesteśmy na stacji benzynowej, łapiemy uchwyt w autobusie, zamykamy się w kabinie publicznej toalety, czy kładziemy monety na szklanej podkładce przy kasie w sklepie. Reklama zewnętrza narzuca wszystkim kontakt wzrokowy, rozpraszając uwagę powoduje, zagrożenie dla ruchu drogowego.

$\mathrm{Z}$ drugiej zaś strony reklama miejska w umiejętny sposób wkomponowana w przestrzeń w postaci billboardów, neonów czy świetlnych ekranów może być integralną częścią architektury, dodawać miastu życia, kolorytu i swoistego wielkomiejskiego rytmu. ${ }^{6}$

Okazuję się jednak, że tylko bardzo silnie wykrystalizowane przestrzenie publiczne są w stanie zapanować nad żywiołem reklam na elewacjach. Niektóre mogą być nawet zbawienne dla źle zaprojektowanej architektury. Katastroficzne dla sztuki jest z kolei obecność reklamy na elewacjach zabytkowych czy w krajobrazach otwartych terenów. Wszystko to prowadzi do upadku wizualnych i estetycznych wartości przestrzeni publicznej. Wielko powierzchniowa reklama, przysłaniająca elewację zabytkowych budynków, odbiera również ludziom jedyną możliwość identyfikacji danego obiektu jak i orientacji w terenie. Trudo zatem dostrzec w przestrzennym chaosie reklamowych takiego ich rozmieszczenia aby nie wpływały na ludzkie zachowania. Według Gehla, podstawowym znaczeniem dla atrakcyjności życia w mieście jest przestrzeń publiczna rozumiana jako miejsce opcjonalnych, swobodnych, bezinteresownych zachowań jak spacerów czy wypoczynku ale również jako przestrzeń spoteczna kontaktów międzyludzkich, jak również innych form aktywności życia w mieście.7 Nadmiar reklamy zakłóca spokój oraz społeczne, swobodne relacje międzyludzkie.

Reklama jest złożonym zjawiskiem współczesnej kultury masowej, a jej wpływ na ludzkie życie można by porównać $\mathrm{z}$ oddziaływaniem treści religijnych, czy mitologicznych na człowieka. $^{8}$

Przed nachalną reklamą brak jest ucieczki a co z autentyczną sztuką w przestrzeni publicznej? Gdzie można ją spotkać po za galeriami i muzeami?

Przez ostatnie kilka lat w miastach pojawia się coraz więcej projektów artystycznych w przestrzeni publicznej. Sztuka w przestrzeni publicznej traktowana jest jako obszar debaty społecznej, jest jednym ze sposobów zabierania w niej głosu krytycznego, jak również promującego poszczególne wydarzenia z życia społecznego.

Obecnie coraz mniej słyszy się głosy sprzeciwu, które podważały by prawo obecności sztuki w przestrzeni publicznej. Wbrew prognozom niektórych teoretyków, nie straciła ona całkowicie znaczenia swojej funkcji. Nawet w coraz większym stopniu przestrzeń publiczna staje się tożsama ze sferą publiczną. ${ }^{9}$

Zastanówmy się teraz i spróbujmy odpowiedzieć na pytanie czy istnieją w przestrzeni miejskiej granice dla artystycznych poczynań oraz innych działań poruszających społecznie istotny problem. Na ile artyści mogą działać w przestrzeni publicznej, aby nie wymagało to zgody zamieszkujących tam osób?

6 Remisko B., 2010. Wizualne zaśmiecanie miast, s. 30-38.

7 Gehl J., 2009. Życie między budynkami. Użytkowanie przestrzeni publicznych, Kraków, s. 9-14.

8 Bażański E., 2004. Kulturowe uwarunkowania percepcji reklamy, Wrocław, s. 212.

9 Nawratek, 2008. K., Miasto jako idea polityczna, korporacja ha!art, Kraków, s. 74. 
Przestrzeń publiczna to obszar, w którym dziatania skierowane sa przede wszystkim na zbudowanie porozumienia między jego użytkownikami10 W przypadku koncepcji agonistycznych - przestrzeń publiczna jest naznaczona konfliktem i walką o hegemonię. Przestrzenie publiczne - maja zawsze charakter warstwowy i sa hegemonicznie ustrukturowane. Dana hegemonia wynika ze specyficznego połaczenia wielości różnych przestrzeni, a to oznacza, że walka hegemoniczna obejmuje również próbę stworzenia innej formy połaczenia między przestrzeniami publicznymi.11 Istotny jest tutaj wpływ sztuki, która przez fakt interwencji w przestrzeń publiczną ma polityczny charakter. Możemy zatem stwierdzić że miejskie przestrzenie publiczne rządzą się innymi regułami niż te w przestrzeni prywatnej, ponieważ związane są z produkcją i reprodukcją porządku demokratycznego.

Istnieje też szereg przestrzeni, które nie są jednoznacznie nie sklasyfikowane. Należą do nich podwórka, osiedla zamknięte, osiedlowe place zabaw czy fasady prywatnych budynków, których to publiczny status zmienia się $\mathrm{w}$ zależności od tego, jak się $\mathrm{z}$ nich korzysta, oraz czy są publicznie dostępne. Na przykład murale o tematyce politycznej powodują że dany budynek zabiera głos w debacie publicznej czy politycznej, stając się przestrzenią działań artystycznych.

W sposób dynamiczny przesuwają się granice pomiędzy tym co nazywamy publicznym, od tego co nią nie jest a przestrzeń miejska traci swój publiczny charakter. Jednak Brugman podkreśla, że przestrzeń publiczna jest nie tylko użytkowana, ale jest również przedmiotem dyskusji różnych aktorów społecznych (mieszkańców, organizacji, władz miasta), w których przeplataja się interesy publiczne i prywatne. W wizji miasta Brugmana nie istnieje granica pomiędzy tym, co prywatne i publiczne. Miasto jest złożonym systemem, a granica ta jest ptynna. Przestrzenia życia społecznego nie jest przestrzeń publiczna tylko obszar, w którym mamy do czynienia z tak zwana , , sztuka w przestrzeni publicznej..$^{12}$

$\mathrm{Na}$ tej podstawie możemy sądzić, że każda przestrzeń społecznie użytkowana (prywatna czy miejska) może stać się przestrzenią publiczną, a tym samym wejść w obszar debaty publicznej. Zatem możemy zadać sobie pytanie, czy artysta powinien wkraczać, w każdą przestrzeń, którą uzna za wartościową dla odtworzenie swojej sztuki nie licząc się z oporami lokalnych mieszkańców? Odpowiadając na to pytanie z perspektywy sztuki zapewne była by ona twierdząca, gdyż jedną z cech sztuki jest przekraczanie granic oraz penetracja nowych obszarów. Jak pokazały badania z końca 2010 na temat wpływu sztuki w przestrzeni publicznej roku, tego typu działania nie powinny stać się elementem spornym. Istnieje kilka przykładów warszawskich projektów np.: Guma (2010) Pawła Althamera, które pokazują że często dana społeczność potrzebuje czasu aby oswoić się z danym obiektem. Jak się potem okazuje początkowa niechęć społeczna zanika a dany obiekt zostaje uznany i na stałe wnika w otoczenie. ${ }^{13}$

Pozytywny stosunek do sztuki w miejskiej przestrzeni publicznej, możliwy jest jeśli swoją obecnością podnosi ona jakość lub nadaje nową tożsamość miejscu tworząc nowy profil danej dzielnicy. Z kolei pojawienie się sztuki w przestrzeni miejskiej nie powinno wpływać na zmianę profilu społecznego danej dzielnicy.

Duża część projektów artystycznych wkraczających w przestrzeń publiczną ma negatywny wydźwięk, ale druga ich część prowadzi do polepszenia jakości przestrzeni i wzmocnienia więzi sąsiedzkich. Artystyczna interwencja w przestrzeń publiczną ma pozytywne skutki, jeśli

10 Ibid.

11 Mouffe Ch., Agonistyczne przestrzenie publiczne i polityka demokratyczna, [w:] Krzysztof Wodiczko, Pomnikoterapia, Warszawa 2005, s. 10.

12 Brugman J., Welcome to Urban Revolution. How Cities Are Changing the World, Thomson Press, London 2009, s. 231

13 Erbel J., K. Herbst, Sztuka w przestrzeni publicznej. Raport z badania, [w:] Liberated Energy, J. Baranowska, P. Sztarbowski, Warszawa 2011, s. 154-171. 
posiada elementy długofalowego procesu i opiera się na pracy z lokalną wspólnotą. Takie inicjatywy uświadamiają mieszkańców, że warto działać i pracować dla poprawy otoczenia oraz że mogą oni mieć wpływ na wygląd, infrastrukturę i charakter miejsca, w którym żyją.

Można uznać, że artyści i artystki nie mają obowiązku współpracy z daną wspólnotą, na której terenie działają. Nie powinni jednak ignorować negatywnych skutków swoich działań a projekty poruszające kwestie społeczne powinny mieć ciąg dalszy, przyczyniając się do rewitalizacji społecznej danej okolicy.

\title{
PIŚMIENNICTWO
}

Bażański E., 2004. Kulturowe uwarunkowania percepcji reklamy, Wrocław s. 212.

Brugman J., 2009. Welcome to Urban Revolution. How Cities Are Changing the World, Thomson Press, London s. 231.

Erbel J., K. Herbst, 2011. Sztuka w przestrzeni publicznej. Raport z badania, [w:] Liberated Energy, J. Baranowska, P. Sztarbowski, Warszawa, s. 154-171.

Gehl J., Życie między budynkami. Użytkowanie przestrzeni publicznych, Kraków 2009, s. 9-14.

Golka M., 1993. Rynek sztuki. Warszawa, s. 10.

Mouffe Ch., 2005. Agonistyczne przestrzenie publiczne i polityka demokratyczna, [w:] Krzysztof Wodiczko, Pomnikoterapia, Warszawa, s. 10.

Nawratek, K., 2008. Miasto jako idea polityczna, korporacja ha!art, Kraków, s. 74 oraz s. 260-261.

Nowa Encyklopedia Powszechna PWN, Warszawa, s. 487

Remisko B., 2010. Wizualne zaśmiecanie miast, s. 30-38.

Tomkins C., 2001. Duchamp. Biografia, Poznań, s. 97.

Kuśmierski S., 2000. Reklama jest sztuka, Warszawa, s. 57 oraz s. 90-101.

http://takeme.pl/toread/publikacja/216/Katastrofa_estetyczna_Reklama_w_przestrzeni_publicznej; data odczytu: 21.10.2015 r.

http://www.wiadomosci24.pl/artykul/sztuka_w_reklamie_czy_reklama_w_sztuce_71082.html; data odczytu: 18.11.2015 r.

http://sztuka.dlastudenta.pl/artykul/Pop_art_Sztuka_w_reklamie,104111.html;11.11.2015 r.

http://www.wykop.pl/ramka/2412236/sztuka-w-reklamie-reklama-w-sztuce/; data odczytu: 11.12.2015 r.

http://marketingwpigulce.pl/sztuka-w-sluzbie-marketingu/; data odczytu: $11.11 .2015 \mathrm{r}$

http://www.survival.art.pl/,122 data odczytu; 07.11.2015 r.

\section{ADVERTISEMENT IN ART, ART IN ADVERTISEMENT IN CONTEXT OF PUBLIC SPACE}

\begin{abstract}
Formerly the advertisement was a primitive agreement between the producer and the consumer. Since the beginning of the twentieth century advertising spread on a massive scale. The universality of the impact of advertising on human life took on the sociocultural dimension. It is said not only that advertising is changing a person's life but also that shapes his personality. The purpose of advertising is typically provide information about the product, to convince consumers of its benefits, causing interest and stimulate the desire to have the goods. However, using advertising, be aware of the fact that its dual nature: on the one hand, it has the character of creative arts, on the other hand, in terms of its effectiveness and efficiency impacts. The following article is an attempt to show the fine line between what is considered art has and what is commercialism. It is a representation of the changes that have taken place in the arts, which contributed to blur the boundaries between what is creative and imitative, what is public and what is not.
\end{abstract}

Keywords: advertising, art, public space, architecture, work of art, kitsch 